gija: prikrivanje i pretjerivanje $«$, Billig Michael Billig

\title{
Learn to Write Badly: How to Succeed in the Social Sciences
}

Cambridge: Cambridge University

Press, 2013, 234 str.

Nova knjiga Michaela Billiga, profesora društvenih znanosti na Sveučilištu Loughborough u Ujedinjenom Kraljevstvu, na zabavan se način bavi vrlo ozbiljnom temom - time kako i zašto znanstvenici/e pišu (loše) u području društvenih znanosti. U knjizi Learn to Write Badly: How to Succeed in the Social Sciences (Učite pisati loše: kako uspjeti u društvenim znanostima) Billig povezuje uvjete rada u društvenim znanostima s lingvističkom prirodom onoga što znanstvenici/e pišu. Pritom autor upozorava kako na taj međuodnos utječe i sve snažnija kultura komercijalizacije u kojoj su sveučilišta, fakulteti i znanstveni instituti u međusobnoj konkurenciji. Kroz devet poglavlja, odnosno kroz uvodno te zaključno poglavlje s preporukama te poglavlja »Masovno objavljivanje i akademski život», »Učite pisati loše«, »Žargon, imenice i akronimi«, »Pretvaranje ljudi u stvari«, »Kako izbjeći reći tko što radi«, »Neke sociološke stvari: vladalaštvo, kozmopolitizacija i analiza razgovora« i »Eksperimentalna socijalna psiholopokazuje kako je kultura natjecanja prožela i akademsko pisanje. U prvi plan dolaze želja za samopromocijom te zadovoljavanje određenih nametnutih indikatora uspješnosti znanstvene produkcije koji ponekad postaju sami sebi svrhom.

Billig dakle upozorava na problem samog sustava znanosti čiji diktum za što više objavljenih radova, s naglaskom na čimbenicima utjecaja (impact factor), na većoj citiranosti i sl., uzrokuje, između ostalog, i prisilu za što bržim objavljivanjem, što uzrokuje i nepažnju u pisanju. Nadalje, autor smatra da se pod krinkom znanstvene neutralnosti pretjerano koristi žargon te se upotrebljava i sve veći broj imenica (umjesto npr. glagola koji govore o nekom odnosu aktera, što Billig smatra važnijim za društvene znanosti) te skraćenica. Upotrebom »tehničkog« jezika koji za sobom povlači i pojačanu primjenu pasiva dolazi do nejasnoća $u$ tekstu i stječe se dojam kako se metodološki okvir i/ili rezultati istraživanja prikrivaju. Billig također upozorava na to da zbog potrebe za što više i što brže objavljenih radova, dolazi i do repetitivnosti u različitim tekstovima te se pojavljuje i fenomen prozvan »rezanje kobasice« (salami slicing) - kad istraživači/ce iz jednog istraživačkog projekta pokušavaju iznjedriti što veći broj izvornih znanstvenih članaka. Na kraju to rezultira lošim znanstvenim tekstovi- 
ma koji nam sve više toga prikrivaju, a sve manje toga otkrivaju.

Billig koristi velik broj primjera iz niza znanstvenih tekstova kako bi pokazao što on podrazumijeva pod »lošim pisanjem« i pritom ne štedi mnoge autore/ice. Iako se ograđuje time da njegova kritika nije zasnovana na estetskim nego na lingvističkim karakteristikama pisanja u društvenim znanostima, ne može se ne oteti dojmu da Billig ipak preferira određeni stil ali i određene teorijske pravce. Naime, Billigu se može i mora prigovoriti na njegovu pozitivističkom pristupu znanstvenom izričaju; on kao da ne propituje svoju epistemološku pozadinu, nego gleda na vlastiti lingvistički pristup kao jedini pravi pristup izražavanju u društvenim znanostima. Pritom se mora primijetiti da bilo što što dolazi izvan anglosaske tradicije ( $\mathrm{tj}$. u Billigovu slučaju francuska i njemačka teorijska tradicija) za njega rezultira samo daljnjim znanstvenim zavrzlamama koje istraživače/ ice vode na krivi istraživački i spisateljski put. Prisilno pojednostavljivanje koncepata nekih autora/ica (gdje je kod Billiga osobito loše prošao Bourdieu) upućuje i na (namjerno) nerazumijevanje terminologije te pristran pogled na određene teorijske i metodološke pristupe.

Doduše, problemi na koje Billig upozorava ne postoje samo u Ujedinjenom Kraljevstvu pa je ova knjiga zanimljiva i za hrvatske prilike. Njegova lingvistička analiza radova jednog dijela znanstvene produkcije u hrvatskom lokalnom kontekstu mogla bi biti prošire- na problemima razvoja znanstvene terminologije. Potonji bi problemi trebali biti sagledani i u svjetlu novog Zakona $o$ znanstvenoj djelatnosti $i$ visokom obrazovanju, novog-starog Pravilnika o uvjetima za izbor u znanstvena zvanja te prijedloga Strategije obrazovanja, znanosti i tehnologije. Lingvistički gledano, mnogi od navedenih problema, a tiču se engleskoga jezika, stoje i za hrvatsku znanstvenu produkciju jer se ona sve više događa na engleskom jeziku, a zbog novih javnopolitičkih (policy) preporuka i instrumenata znanstvene politike resornog ministarstva engleski će biti još i više jezikom lokalne zajednice gdje će hrvatski jezik postati »neisplativ« za pisanje i daljnje razvijanje. Problemi koje navodi Billig u svojoj knjizi u hrvatskom bi lokalnom kontekstu mogli biti prošireni i problemima prijevoda znanstvene terminologije, nedostatka obrazovnih programa iz akademskog pisanja te manjka prakse rada na znanstvenim tekstovima.

Bez obzira na to koliko se ne moramo složiti s mnogim tezama pa čak $\mathrm{i}$ načinom na koji Billig izlaže neke od svojih tvrdnji ipak se možemo složiti s njim da trenutačni sustav znanosti pod procesima komercijalizacije dovodi i do nedovoljno kvalitetno obrađenih tekstova. Doduše, može se, s jedne strane, primijetiti i jedna romantičarska nota kod Billiga kad govori o »dobrim starim vremenima« kad društvene znanosti nisu bile toliko fragmentirane, kad nije bilo toliko (jezika) disciplina te je bilo puno jednostavnije ulaziti u druge discipline. Međutim, ne možemo po- 
bjeći od toga da se znanost razgranala i razvila pa bi bilo čudno očekivati da je akademski diskurs ostao jednak kad se u međuvremenu pojavio i širi niz problema, procesa koji prije nisu mogli biti ni istraživani ni imenovani. Doduše, Billig dobro upućuje na problem društvenog konteksta cijelog sustava $u$ kojem »proizvodnja ne smije stati«, a upravo je znanost takva da traži vrijeme za preispitivanje, preispisivanje i pojašnjavanje. U uvodnom poglavlju Billig primjećuje da je i sam naslov knjige izabrao tako da zvuči poput popularnih knjiga samopomoći; ono što je porazno za znanstvenu zajednicu jest da kad bi netko tu šalu shvatio ozbiljno čak bi na kraju, na žalost (a na svoju sreću), mogao vrlo dobro proći.

Jaka Primorac

Institut za razvoj $i$ međunarodne odnose, Zagreb

DOI: $10.5613 /$ rzs.43.1.6

\section{Sarah J. Tracy}

\section{Qualitative Research}

Methods: Collecting

Evidence, Crafting Analysis, Communicating Impact

Chichester, West Sussex, UK: WileyBlackwell, 2013, 350 str.

Posegnuti za još jednim priručnikom s engleskoga govornog područja iz kvalitativnih metoda istraživanja zadnjih je godina poprimilo karakteristike samonametnutog déjà vua. Većina te udžbeničke produkcije pretjerano je slična po temama, načinu obrade i prezentacije sadržaja, ali često - na žalost - i po površnosti. Premda svi autori/ce pokušavaju pokazati da je upotreba kvalitativnih metoda složena i zahtjevna, mnoge elemente te kompleksnosti prikazuju na anegdotalan i gotovo estradni način. Na prvi pogled ni knjiga Sarah J. Tracy Qualitative Research Methods: Collecting Evidence, Crafting Analysis, Communicating Impact nije lišena uobičajenih mana, no zbog nekoliko joj razloga ipak vrijedi pokloniti više pozornosti. Naime, knjiga slijedi projektnu logiku uz istovremenu teorijsku potkrjepu i praktične iskustvene terenske primjere, bez nepotrebne mistifikacije istraživačkog procesa.

Sarah J. Tracy izvanredna je profesorica iz područja ljudske komunikacije na Arizona State University - Tempe. Poučava i piše o kvalitativnim metodama u kontekstu istraživanja emocionalnog rada, blagostanja i ljudskih odnosa u radnim organizacijama. Kako sama autorica navodi u životopisu na službenim stranicama sveučilišta na kojemu je zaposlena, najviše se oslanja na etnografske pristupe u naturalističkom kontekstu. Zanimaju je konkretna istraživanja koja mogu biti iskorištena za planiranje i provođenje učinkovitih zahvata i promjena. Upravo su zato ta istraživanja projektno zaokružena i usmjerena na rješavanje problema $u$ uspostavljanju ravnoteže između svakodnevnog života i zaposlenja »stvar- 